ISSN 0103-5150

Fisioter. Mov., Curitiba, v. 30, n. 3, p. 443-451, Jul./Sep. 2017

Licenciado sob uma Licença Creative Commons

DOI: http://dx.doi.org/10.1590/1980-5918.030.003.A002

\title{
Therapeutic ultrasound associated with copaiba oil reduces pain and improves range of motion in patients with knee osteoarthritis
}

\author{
Ultrassom terapêutico associado ao óleo de copaíba \\ reduz a dor e melhora amplitude de movimento \\ de pacientes com osteoartrite de joelho
}

Luis Fernando Sousa Filho, Jessica Batista de Souza, Grace Kelly Melo de Almeida, Itamar Couto Guedes de Jesus, Evaleide Diniz de Oliveira*

Universidade Federal de Sergipe (UFS), Centro de Ciências Biológicas e da Saúde, São Cristovão, SE, Brazil

\begin{abstract}
Introduction: Osteoarthritis is a disease that affects millions of Brazilians. Therapeutic ultrasound has been used in its treatment, either alone or associated with drugs. Objective: The aim of this study was to evaluate the effects of ultrasound (US) associated with Copaiba oil (CO) on knee osteoarthritis. Methods: Patients were divided into three different groups: US, US+CO, CO.Ten treatment sessions were held twice a week, 30 minutes each.Pain intensity was assessed through the Visual Analog Scale (VAS) and Range of Motion (ROM) by goniometry, and muscle strength was assessed by means of the Medical Research Council Scale. Statistical analysis was performed by Cohen's d test, student's t test and ANOVA, considering $\mathrm{p}<0.05$ as significant. Results: Pain reduced in all groups.The US+CO group $(\mathrm{d}=-3.50)$ presented larger effect size when compared to the other groups. Regarding ROM, the largest effect size was observed in the US+CO group for flexion $(d=0.86)$ and extension $(d=0.97)$ in comparison with the remainder groups.Muscle strength increased in the US $(d=1.54)$ and US+CO $(d=1.60)$ groups for flexion.Regarding extension, the US group presented the
\end{abstract}

\footnotetext{
LFSF: BS, e-mail: fernandosouf@hotmail.com JBS: BS, e-mail: jess_bs@hotmail.com GKMA: Doctoral Student, e-mail: gracekellymelo@hotmail.com ICGJ: Master Student, e-mail: itamarcouto_g@hotmail.com EDO: PhD, e-mail: evaleide@uol.com.br
} 
largest effect size $(\mathrm{d}=1.80)$. Conclusion: Therapeutic ultrasound associated with copaiba oil is a practical and effective therapy for the treatment of inflammatory diseases such as osteoarthritis.

Keywords: Ultrasound. Osteoarthritis. Pain.

\section{Resumo}

Introdução: A osteoartrite é uma doença que afeta milhões de brasileiros. O ultrassom terapêutico tem sido utilizado em seu tratamento tanto sozinho, quanto associado a fármacos. Objetivo: Avaliar o efeito do ultrassom (US) associado ao óleo de copaíba (OC) em pacientes com osteoartrite de joelho. Métodos: Os pacientes foram distribuídos em 3 grupos distintos: US, US+OC e OC. Foram realizadas 10 sessões de tratamento, duas vezes por semana durante 30 minutos. A intensidade da dor foi avaliada pela Escala Visual Analógica da Dor (EVA), amplitude de movimento ADM pela goniometria e força muscular pelo Score Medical Research Council. A análise estatística foi feita pelo Teste T de Student e ANOVA e a magnitude do efeito (d), considerando $p<0,05$ como valores significativos. Resultados: A dor foi atenuada em todos os grupos, sendo apresentada uma magnitude maior do efeito para o grupo US+OC $(d=-3,50)$ quando comparado aos demais grupos. Em relação a $A D M$ a magnitude do efeito foi maior no grupo US+OC $(d=0,86)$ para a flexão e extensão $(d=0,97)$ quando comparados com os outros grupos. Na variável força muscular os grupos US $(d=1,54)$ e $U S+O C(d=1,60)$ foram mais eficazes no movimento de flexão e na extensão, o grupo US exibiu o maior tamanho de efeito $(d=1,80)$ quando comparados aos demais grupos. Conclusão: O ultrassom terapêutico associado ao óleo de copaíba é uma terapia efetiva e prática para o tratamento de doenças inflamatórias, tais como a osteoartrite.

Palavras-chave: Ultrassom. Osteoartrite. Dor.

\section{Introduction}

Osteoarthritis $(\mathrm{OA})$ is a degenerative joint disease that affects nearly 10 million Brazilians, and this figure is expected to reach 30 million in 2020 (1). The potential of osteoarthritis for promoting disability is worth of notice. According to the Brazilian Rheumatology Society, osteoarthritis accounts for $7.5 \%$ of medical leaves, and it isranked fourth in diseases that lead to retirement, with $6.2 \%$ (2).

Osteoarthritis is a clinical joint pain syndrome followed by different degrees of functional limitation and reduced quality of life. It is considered to be a multi-factor disorder with no defined primary cause that, after being developed, can manifest in the form of edema to joint deterioration (3). Some factors can contribute to the disease development, such as obesity and advanced age (4).

Up to now, there is no therapy to reverse changes caused by this degenerative disease. The therapy's main objectives are to reduce pain and improve the function of joints affected. According to the American Rheumatology College (5) the main therapies applied are pharmacological therapies, non-pharmacological therapies or alternative therapies (including physical exercise and body masscontrol) and, for more critical cases, surgery.

Therapeutic ultrasound (US) is an alternative therapy commonly used by physiotherapists, and consists in applying ultrasonic waves that, through their vibrating effect, promote cell changes that result in alterations of the ionic gradient and acceleration of the tissue repairing process (6). A previous study showed that US has worked favorably in the therapy of myofascial pain (7), subacromial impact syndrome (8), lesions of soft tissues (9) and shoulder tendinitis (10).

Although being very popular, the efficacy of using US to treat osteoarthritis is not totally defined. In a previous study (11), US reduced pain and, therefore, increased the mobility of patients with mild knee osteoarthritis. On the other hand, Ulus et al. (12) observed that US did not bring more significant improvements to a control group for the variables of pain, physical function, disability and psychological state of patients with knee osteoarthritis. The latest Cochrane database review (13) suggests that therapeutic ultrasound should present beneficial effects on 
pain and function of patients with knee osteoarthritis, although the size of such effects remains unclear. The oldest version had concluded that ultrasound benefits were not higher than those of placebo (14).

In addition to its conventional use, in the last few decades, US has been used for physical therapies to promote cutaneous permeation of medicines, facilitating cutaneous absorption (15). Therefore, the topical application of drugs on the outer layer of the skin is directed by the US to the underlying tissues, increasing local concentration of the drug (16). Kozanoglu et al. (17) compared the effects of therapeutic US associated with Ibuprofen and the conventional US. They concluded that although both modalities have been efficacious for the treatment of patients with osteoarthritis, improvement with US associated with Ibuprofen was not better than that with the conventional US. In contrast, Toopchizadeh et al. (18) associated US with Dexamethasone and reached better results than with US alone on pain reduction and function improvement.

Ultrasound is usually associated with antiinflammatory and anesthetic drugs (19). Copaíba oil (CO) is a Brazilian typical natural product with powerful anti-inflammatory activity $(20,21)$. It has been used in popular medicine for centuries and is one of the main Amazonian products traded in the United States and Europe $(22,23)$. In addition to being anti-inflammatory, Copaíba oil has antimicrobial (24), antinociceptive (25), antitumor (26) and antiseptic (27) properties. Most of these properties were discovered through in vitro experimentations. Little is known about the effect of Copaíba oil on humans, although it is commonly used to treat musculoskeletal disorders.

Considering the broad range of biological effects presented by the properties of Copaíba oil and therapeutic ultrasound, this study is based on the hypothesis that the association of both could result in a more efficacious osteoarthritis therapy since their mechanisms tend to mitigate tissue inflammation and, thus, improve patients' algic and functional conditions. Therefore, the study objective was to evaluate the effect of therapeutic ultrasound associated with Copaíba oil on variables of pain, ranges of motion and muscle strength of patients with knee osteoarthritis.

\section{Methods}

This is a randomized study developed at the Kinesiotherapy Laboratory of the Physiotherapy Department, at the Sergipe Federal University (UFS). Treatment groups were made up of 90 women -30 in each group - with clinical diagnosis of knee osteoarthritis (ICD - M.17) grade II according to Ahlback's (28) classification, with inflammation in sub-acute stage, ambulation conditions and stable hemodynamic state. All patients were registered on the waiting list for rheumatologic care at the UFS teaching hospital outpatient unit, with ages ranging from 45 to 75 years old. No patient quit the proposed therapies.

Patients were randomly divided into three groups: ultrasound group (US); ultrasound group associated with Copaíba oil (US+CO) and a Copaíba oil group (CO). The randomized sequence was generated using a computer. Randomization occurred following the order of inclusion of each patient in the study, according to the list generated by a computer before starting the study. The randomization block was created to generate sequences of allocation and ensure balance of participants in each group at any time during the study. After each block, the number of participants in each group would be equivalent, in the 1:1 ratio.

Total treatment was carried out in ten sessions delivered twice a week, 30 minutes each. All participants were given a free and informed consent form for analysis and, if they agreed with it, they should sign the form and become volunteers of the study (CAAE-0004.0.107.000-09).

The therapeutic effect of Copaíba oil was evaluated in groups, as well as if the oil effect was optimized after using ultrasound. Patients in the US group were subject to the application of $20 \%$ pulsed ultrasound previously calibrated with intensity of $0.8 \mathrm{w} / \mathrm{cm}^{2}$ (SATP), transducer frequency of $1 \mathrm{MHz}$ (Ibramed, Sonopulse model) for 8 minutes followed with massage therapy (circular movements, with light pressure) with mineral oil for five minutes on the knee. Patients in the US+CO group were subject to the application of pulsed ultrasound, in the same standards as the US group, followed by massage therapy with Copaíba oil $(100 \%, 0.3 \mathrm{~mL})$ for five minutes on the knee. The CO group patients, in turn, were treated only with massage therapy for five minutes with Copaíba oil. After massage (circular movements with light pressure) patients from 
all groups were subject to assisted, active-assisted and resisted, free-active kinesiotherapy to supplement treatment through stretching, strengthening and muscle proprioception. Exercises were the same in the three groups. Kinesiotherapy was included to ensure proper therapy to all patients, as consolidated in scientific literature for the pathology in question, since in our study hypothesis ultrasound associated with Copaíba oil was in experimentation with no assurance of its efficacy.

The variables investigated in the study were evaluated in the first and tenth treatment session. Pain intensity was assessed using the Pain Visual Analog Scale (VAS) (29). Patients were instructed to mark their level of pain on the scale. Range of motion was measured using a goniometer. Goniometry is validated and reliable for the measurement of knee joint angles (30). The muscle strength degree was evaluated through the Medical Research Council Scale. The examiner's subjective perception was based on a scale ranging from 0 to 5 , where 0,1 and 2 degrees are tested in a position in favor of gravity. All the remainder degrees are tested in a position opposite to the force of gravity $(31,32)$.

The results achieved were statistically analyzed using Student's t test and the Analysis of Variance (ANOVA), being represented by means and standard deviation (SD) values. The t test was used for intra-group evaluations of all variables. ANOVA oneway (post-Tukey's test) was used for intergroup evaluations. The d effect, or Cohen's d, was calculated to evaluate treatments' effect size. Effect d corresponds to the standard difference among the means of the compared groups, divided by the standard deviation of the comparison. According to Cohen, values of 0.2, 0.5 and 0.8 stand for small, medium or large effect, respectively (33). All analyses used the Graph Pad Prism (version 5.1) software considering significance level of $95 \%(\mathrm{p}<0.05)$ for all tests.

\section{Results}

Age, height, weight and body mass index (BMI) of patients in different groups were measured and compared to one another (one-way ANOVA). The CO group $(81 \pm 7.6 \mathrm{Kg})$ presented a statistically significant difference when compared against the US group $(74 \pm 8.9 \mathrm{Kg})$ regarding the variable of weight with $\mathrm{p}=0.0193$. Regarding BMI, the CO group $\left(34.5 \pm 6.2 \mathrm{Kg} / \mathrm{m}^{2}\right)$ was statistically different from the US group $\left(29 \pm 2.4 \mathrm{Kg} / \mathrm{m}^{2}\right)$ and from the US+CO group $\left(29.4 \pm 7.2 \mathrm{Kg} / \mathrm{m}^{2}\right)$, with $\mathrm{p}=0.0011$. The remainder variables did not present significant differences as shown in Table 1.

Table $\mathbf{1}$ - Comparison of age, height, weght and BMI of patients in different groups

\begin{tabular}{lcccc}
\hline \multicolumn{1}{c}{$\begin{array}{c}\text { Patients' } \\
\text { characteristics }\end{array}$} & US $(\mathrm{n}=30)$ & US $+\mathrm{CO}(\mathrm{n}=30)$ & $\mathrm{CO}(\mathrm{n}=30)$ & $P$ value \\
\hline Age (years) & $61.8 \pm 12.5$ & $61.1 \pm 8.2$ & $61.4 \pm 9.9$ & 0.9961 \\
Height $(\mathrm{cm})$ & $160 \pm 10.0$ & $162 \pm 10.0$ & $163 \pm 12.3$ & 0.5523 \\
Weight $(\mathrm{kg})$ & $74.0 \pm 8.9$ & $77.3 \pm 11.4$ & $81.0 \pm 7.6$ & $0.0193^{*}$ \\
BMl $\left(\mathrm{Kg} / \mathrm{m}^{2}\right)$ & $29.0 \pm 2.4$ & $29.4 \pm 7.2$ & $34.5 \pm 6.2$ & $0.0011^{* *}$
\end{tabular}

Note: Data are presented in means and standard deviation, $(n=30) . S D=$ standard deviation. $B M I=$ body mass index. US = therapeutic ultrasound. US + CO = therapeutic ultrasound + Copaíba oil. CO = Copaíba oil.

The variable pain was assessed through VAS scores. Table 2 shows that VAS scores were significantly reduced after therapies ( $\mathrm{p}<0.0001)$. The effect size of the US+CO $(d=-3.50)$ group was larger when compared to that of the US group $(\mathrm{d}=-2.90)$ and the CO group $(\mathrm{c}=-1.50)$. 
Table 2 - Differences between pain intensity before and after therapy

\begin{tabular}{lcccc}
\hline \multicolumn{1}{c}{ Groups } & Before & VASScores & & \\
\hline US $(\mathrm{n}=30)$ & $3.1 \pm 1.0$ & $0.8 \pm 0.5$ & -2.90 & $<0.0001^{* * *}$ \\
US + CO $(\mathrm{n}=30)$ & $5.4 \pm 1.9$ & $0.4 \pm 0.5$ & -3.50 & $<0.0001^{\star * *}$ \\
CO $(\mathrm{n}=30)$ & $4.6 \pm 2.2$ & $1.2 \pm 2.2$ & -1.50 & $<0.0001^{\star * *}$
\end{tabular}

Note: Results are expresses through mean and standard deviation. D effect represents the effect size of each group ( $n \star 30)$. VAS $=$ Visual Analog Scale US $=$ therapeutic ultrasound. US $+\mathrm{CO}=$ therapeutic ultrasound + Copaíba oil. $\mathrm{CO}=$ Copaíba oil.

Range of motion was evaluated by goniometry on joint movements of knee flexion and extension during the 1st and 10th therapy sessions. In the flexion movement, the US+CO $(\mathrm{d}=0.86)$ group presented the largest size effect when compared to the US group $(\mathrm{d}=0.57)$ and the CO group $(\mathrm{d}=0.07)$. The US $(p=0.0299)$ and the US+CO $(p=0.0015)$ groups presented significant differences before and after treatment (Table 3). Extension movement presented similar results. The US ( $\mathrm{p}=0.0159)$ and US+CO $(p=0.0004)$ groups presented a statistical intragroup difference, where the US+CO group $(d=0.97)$ presented the largest size effect.

Table 3 - Range of motion assessment. Comparison of range of motion degrees of patients before and after therapy for knee flexion and extension movements

\begin{tabular}{|c|c|c|c|c|}
\hline \multirow[b]{2}{*}{ Groups } & \multicolumn{2}{|c|}{ ROM degrees for flexion } & & \multirow[b]{2}{*}{$P$ value } \\
\hline & Before & After & & \\
\hline US $(n=30)$ & $96.3 \pm 14.1$ & $103.8 \pm 11.9$ & 0.57 & $0.0299 *$ \\
\hline$U S+C O(n=30)$ & $93.2 \pm 21.0$ & $108.8 \pm 14.7$ & 0.86 & $0.0015^{\star \star}$ \\
\hline $\operatorname{CO}(n=30)$ & $96.8 \pm 15.4$ & $98.7 \pm 31.9$ & 0.07 & 0.7700 \\
\hline
\end{tabular}

\begin{tabular}{lcccc}
\hline \multicolumn{1}{c}{ Groups } & \multicolumn{2}{c}{ ROM degrees for flexion } & & \\
\hline US $(\mathrm{n}=30)$ & Before & After & D effect & $P$ value \\
US + CO $(n=30)$ & $-6.9 \pm 7.0$ & $-3.1 \pm 4.6$ & 0.64 & $0.0159^{*}$ \\
CO $(n=30)$ & $-8.5 \pm 5.6$ & $-3.5 \pm 4.6$ & 0.97 & $0.0004^{* \star *}$ \\
\end{tabular}

Note: Results are expresses through means and standard deviation. $D$ effect represents the effect size of each group $(n \star 30)$. ROM $=$ range of motion. US $=$ therapeutic ultrasound. US $+C O=$ therapeutic ultrasound + Copaiba oil. CO = Copaíba oil.

The muscle strength degree was assessed through the Medical Research Council Scale, in knee flexion and extension movements. The US $(\mathrm{d}=1.54)$ and $\mathrm{US}+\mathrm{CO}(\mathrm{d}=1.60)$ groups provided better response to the therapy with size effects similar in flexion movement. Regarding the muscle strengthen degree in extension, the US group reported the largest effect size $(\mathrm{d}=1.80)$ if compared to the remainder groups. The CO group presented the shortest effect size both in flexion $(\mathrm{d}=0.42)$ and extension $(\mathrm{d}=0.74)$.

Table 4 - Muscle strength assessment. Comparison of muscle strength degrees of patients during knee flexion and extension movements, according with the Medical Research Council Scale

\begin{tabular}{lcccc}
\hline \multicolumn{1}{c}{ Groups } & \multicolumn{2}{c}{ Muscle strength degrees for flexion } & \\
\hline US $(n=30)$ & Before & After & 1.54 & $<$ value \\
US + CO $(n=30)$ & $3.4 \pm 0.5$ & $4.1 \pm 0.4$ & 1.60 & $<0.0001^{* * *}$ \\
CO $(n=30)$ & $3.7 \pm 0.5$ & $4.5 \pm 0.5$ & 0.42 & $0.1071^{* * *}$
\end{tabular}




\begin{tabular}{lcccc}
\hline \multicolumn{1}{c}{ Groups } & \multicolumn{2}{c}{ Muscle strength degrees for flexion } & \\
\hline US $(n=30)$ & Before & After & 1.80 & $<$ value \\
US + CO $(n=30)$ & $3.6 \pm 0.5$ & $4.5 \pm 0.5$ & 1.10 & $<0.0001^{* \star *}$ \\
CO $(n=30)$ & $4.0 \pm 0.4$ & $4.5 \pm 0.5$ & 0.74 & $0.0001^{* * *}$ \\
& $3.9 \pm 0.3$ & $4.3 \pm 0.7$ & $0.0056^{\star *}$
\end{tabular}

Note: Results are expresses through mean and standard deviation. $D$ effect represents the effect size of each group $(n * 30)$. US $=$ therapeutic ultrasound. US +CO = therapeutic ultrasound + Copaíba oil. CO = Copaíba oil.

\section{Discussion}

Osteoarthritis therapy aims to reduce pain and improve patients' functional state. Therapeutic ultrasound has been used in osteoarthritis therapy but studies on its efficacy are controversial. This study analyzed the effect of ultrasound associated with Copaíba oil in patients with knee osteoarthritis grade II, comparing it before and after therapy, and found positive results regarding pain, range of motion and muscle strength.

Obesity, advanced age, overweight and female sex are considered risk factors to develop osteoarthritis (34). In this study, all patients were women, with age ranging from 45 to 75 years old, mean of $61.4 \pm 10.2$ years, and no significant differences between groups ( $p=0.9961)$. As regards body weight, patients in the CO group $(81 \pm 7.6 \mathrm{Kg})$ reported having more weight than those in the remainder groups, with a significant difference ( $p=0.0193)$. Likewise, the BMI of patients in the CO group $(34.5 \pm 6.2)$ was significantly higher than that for the other groups ( $\mathrm{p}=0.0011)$. Although a previous study shows that obese individuals present sharper degeneration than individuals of normal weight, all patients part of the study presented osteoarthritis grade II (35).

Therapeutic ultrasound is one of the main nonpharmacological resources used to control pain. However, there are divergences about its efficacy (36). Ulus et al. (37) found no significant differences between the use of US and placebo in the VAS scores for patients with knee osteoarthritis. In our study, US reduced pain after therapy; however, effect presented larger size when compared with the use associated with Copaíba oil. Luk surapan et al. (38) found similar results. A gel traditionally used in association with US to treat musculoskeletal disorders proved to be more efficient to reduce pain than US alone. Copaíba oil presented anti-inflammatory and analgesic properties in in vitro experiences; however, there is no evidence of such effects on patients with osteoarthritis.
The association of US and active substances to relieve pain and improve functionality is used in clinical practices, but there is little scientific evidence supporting this therapy (39). Anti-inflammatory substances like Diclofenac and Ibuprofen are largely used. Rosim et al. (40) showed that previous use of US increased transdermal penetration of Diclofenac gel in healthy individuals. In patients with knee osteoarthritis, the use of US associated with Diclofenac reduced pain and improved ROM in a more significant way than US alone (41). In our study, ultrasound combined with Copaíba oil presented larger effect than ultrasound or Copaíba oil alone to enhance range of motion both in flexion and extension.

Many factors are related to mobility deficit in knee osteoarthritis, including knee pain, strength of the quadriceps and age (42). Cubukcu et al. (43) assessed 114 patients with knee osteoarthritis and concluded that pain, rigidity and duration of the disease affect the patients' functional incapacity. Observing our results, pain reduction and expansion of ROM were proportional among groups, except for the CO group that reported no significant difference between ROM degree before and after therapy. Besides being a factor that restrains the range of motion, pain may lead patients to develop kinesiophobia (44). Therefore, pain reduction may have favored increased ROM. The result for the CO group should be justified by the high BMI of patients in this group. Holla et al. (45) report that in addition to joint degeneration, pain, rigidity and male gender, BMI is also associated with range of motion degrees. Fat accumulation can limit ROM.

Many studies have shown that patients with osteoarthritis present reduced muscle strength $(46,47)$. Slementa et al. (48) already reported that reduced quadriceps strength should be a risk factor for knee osteoarthritis among women. In a recent study, patients with knee osteoarthritis presented less quadriceps strength in comparison with individuals with no osteoarthritis, and this finding was more closely related to increased intramuscular fat than to the 
muscle section area (47). Our results show that ultrasound alone and ultrasound associated with Copaíba oil have significantly increased muscle strength of knee flexor and extensor muscles, whereas Copaíba oil alone presented no changes. Patients tend to avoid movements when they feel pain, and this causes muscle damages. Pisters et al. (49) had previously shown that fearing movements is common among patients with osteoarthritis, leading to reduced muscle strength. Reduction of pain in the respective groups tend to reduce fear of movement as happened with the US and US+CO groups and, therefore, increase muscle strength.

Obesity is related with muscle weakness in patients with osteoarthritis (50). The response of patients treated exclusively with Copaíba oil was weaker in all variables analyzed, including muscle strength. This result could be explained by the high BMI value of patients in this group, when compared against other groups. Conroy et al. (51) observed that patients with knee osteoarthritis, with or without pain, high BMI and high quantity of intramuscular fat show weaker torque specific to the quadriceps against individuals without osteoarthritis.

This study aimed to evaluate the effects of US associated with natural oil in patients with knee osteoarthritis and found positive results on pain, range of motion and muscle strength, in line with findings previously published. However, this study had some limitations: patients and researchers were not blind; effects observed were analyzed only before and immediately after therapy with no long-term monitoring. An important issue was the size of the sample used, i.e., 30 patients in each group. Samples with between 30 and 40 participants are considered large enough to waive the use of normality tests, since these tend to be normally distributed (52).

\section{Conclusion}

Our results showed that ultrasound maximized the Copaíba oil effect and is effective to reduce pain, and increase muscle strength and range of motion. Therefore, associating US with Copaíba oil is a practical and effective therapy for knee osteoarthritis.

\section{References}

1. Coimbra IB, Rezende UM, Plapler PG. Osteoartrite (artrose) - cenário atual e tendências no Brasil. São Paulo: Limay; 2012.

2. Seda H, Seda AC. Osteoartrite (Artrose). 2008 [cited 2014 Aug 10]. Available from: http://tinyurl.com/ jhz8few.

3. Rosis, RC, Massabki OS, Kairalla M. Osteoartrite: avaliação clínica e epidemiológica de pacientes idosos em instituição de longa permanência. Rev. Bras. Clin. Med. 2010;8(2):101-8.

4. Blagojevic M, Jinks C, Jeffery A, Jordan KP. Risk factors for onset of osteoarthritis of the knee in older adults: a systematic review and meta-analysis. Osteoarthritis Cartilage. 2010;18(1):24-33.

5. Hochberg MC, Altman RD, April KT, Benkhalti M, Guyatt G, McGowan J, et al. American College of Rheumatology 2012 recommendations for the use of non pharmacologic and pharmacologic therapies in osteoarthritis of the hand, hip, and knee. Arthritis Care Res (Hoboken). 2012;64(4):465-74.

6. ter Haar G. Therapeutic ultrasound. Eur J Ultrasound. 1999;9(1):3-9.

7. Ilter L, Dilek B, Batmaz I, Ulu MA, Sariyildiz MA, Nas $\mathrm{K}$, et al. Efficacy of Pulsed and Continuous Therapeutic Ultrasound in Myofascial Pain Syndrome: A Randomized Controlled Study. Am J Phys Med Rehabil. 2015;94(7):547-54.

8. Yildirim MA, Ones K, Celik EC. Comparision of Ultrasound Therapy of Various Durations in the Treatment of Subacromial Impingement Syndrome. J Phys Ther Sci. 2013;25(9):1151-4.

9. Binder A, Hodge G, Greenwood AM, Hazleman BL, Page Thomas DP. Is therapeutic ultrasound effective in treating soft tissue lesions? Br Med J (Clin Res Ed). 1985;290(6467):512-4.

10. Ebenbichler GR, Erdogmus CB, Resch KL, Funovics MA, Kainberger F, Barisani G, et al. Ultrasound therapy for calcific tendinitis of the shoulder. N Engl J Med. 1999;340(20):1533-8.

11. Langer MD, Levine V, Taggart R, Lewis GK, Hernandez L, Ortiz R. Pilot clinical studies of long duration, low intensity therapeutic ultrasound for osteoarthritis. Proc IEEE Annu Northeast Bioeng Conf. 2014;2014.pii: 14789673. 
12. Ulus Y, Tander B, Akyol Y, Durmus D, Buyukakıncak $\mathrm{O}$, Gul U, et al. Therapeutic ultrasound versus sham ultrasound for the management of patients with knee osteoarthritis: a randomized double-blind controlled clinical study. Int J Rheum Dis. 2012;15(2):197-206.

13. Rutjes AW, Nüesch E, Sterchi R, Jüni P. Therapeutic ultrasound for osteoarthritis of the knee or hip. Cochrane Database Syst Rev. 2010;(1):CD003132.

14. Welch V, Brosseau L, Peterson J, Shea B, Tugwell P, Wells G. Therapeutic ultrasound for osteoarthritis of the knee. Cochrane Database Syst Rev. 2001;(3):CD003132.

15. Pires-de-Campos MSM, Polacow MLO, Granzotto TM, Spadari-Bratfisch RC, Leonardi GR, Grassi-Kassisse DM. Influence of the ultrasound in cutaneous permeation of the caffeine: in vitro study. Pharmacology online. 2007;1:477-86.

16. Cagnie B, Vinck E, Vanderstraeten G. Phonoforesis versus topical application of Ketoprofen: comparison between tissue and plasma levels. Phys Ther. 2003;83(8):707-12.

17. Kozanoglu E, Basaran S, Guzel R, Guler-Uysal F. Short term efficacy of ibuprofen phonophoresis versus continuous ultrasound therapy in knee osteoarthritis. Swiss Med Wkly. 2003;133(23-24):333-8.

18. Toopchizadeh V, Javadi R, Sadat BE. Therapeutic Efficacy of Dexamethasone Phonophoresis on Symptomatic Knee Osteoarthritis in Elderly Women. Int J Women's Health Reproduction Sci. 2014;2(3):168-77.

19. Byl NN. The use of ultrasound as an enhancer for transcutaneous drug delivery: phonophoresis. Phys Ther. 1995;75(6):539-53.

20. Viriato EP, Bianchetti ES, Santos KC, Vaz AF, Campos RMV, Pereira AP, et al. Study of high dilutions of copaíba oil oninflammatory process. Int J High Dilution Res. 2009;8(26):9-14.

21. Dias DS, Fontes LB, Crotti AE, Aarestrup BJ, Aarestrup FM, Silva Filho AA, et al. Copaiba oil suppresses inflammatory cytokines in splenocytes of $\mathrm{C} 57 \mathrm{Bl} / 6$ mice induced with experimental autoimmune encephalomyelitis (EAE). Molecules. 2014;19(8):12814-26.

22. Pieri FA, Mussi MC, Moreira MAS. Óleo de copaíba (Copaifera sp.): histórico, extração, aplicações industriais e propriedades medicinais. Rev. Bras Plantas Med. 2009;11(4):465-72.
23. Veiga Junior VF, Pinto AC.O gênero copaifera L. Quím Nova. 2002;25(2):273-86.

24. Santos AO, Ueda-Nakamura T, Dias Filho BP, Veiga Jr VF, Pinto AC, Nakamura CV. Antimicrobial activity of Brazilian copaiba oil sobtained from different species of the Copaifera genus. Mem Inst Oswaldo Cruz. 2008;103(3):277-81.

25. Gomes NM, Rezende CM, Fontes SP, Matheus ME, Fernandes PD. Antinociceptive activity of Amazonian Copaiba oils. J Ethnopharmacol. 2007;109(3):486-92.

26. Gomes NM, Rezende CM, Fontes SP,Hovell AMC, Landgraf RG, Matheus ME, et al. Antineoplasic activity of Copaifera multijuga oil and fractions against ascitic and solidehrlich tumor. J. Ethnopharmacol. 2008;119(1):179-84.

27. Botelho NM, Silveira EL, Lopes LN, Santos FA, Teixeira RK, Silva TT. Copaiba oil effect under diferente path ways in mice subject edtosepsis. Acta Cir Bras. 2014;29(8):528-31.

28. Galli M, De Santis V, Tafuro L. Reliability of the Ahlbäck classification of knee osteoarthritis. Osteoarthritis Cartilage. 2003;11(8):580-4.

29. Mob O, Ra A, Ro A. Reliability and concurrent validit yof visual analogue scaleand modified verbal rating scale of pain assessment in adult patients with knee osteoarthritis in Nigeria. S Afr J Physiother. 2003;59(2):12-5.

30. Gogia PP, Braatz JH, Rose SJ, Norton BJ. Reliability and validity of goniometric measurements at the knee. Phys Ther. 1987;67(2):192-5.

31. Medical Research Council. Aids to the examination of theperipheral nervous system. Memorandum No. 45 (superseding War Memorandum No. 7). London: HerMajesty'sStationery Office; 1981.

32. Paternostro-Sluga T, Grim-Stieger M, Posch M, Schuhfried O, Vacariu G, Mittermaier C, et al. Reliability and validity of the Medical Research Council (ROMC) scaleand a modified scale for testing muscles trength in patients with radial palsy. J Rehabil Med. 2008;40(8):665-71.

33. Cohen J. Statistical power analysis for the behavioral sciences (2. Auflage). Hillsdale, NJ: Erlbaum, 1988. 
34. Silverwood V, Blagojevic-Bucknall M, Jinks C, Jordan JL, Protheroe J, Jordan KP.Current evidence on risk factors for knee osteoarthritis in older adults: a systematic review and meta-analysis. Osteoarthritis Cartilage. 2015;23(4):507-15.

35. Muehleman C, Margulis A, Bae WC, Masuda K. Relationship between knee and anklede generation in a population of organdonors. BMC Med. 2010;8:48.

36. Robertson VJ, Baker KG. A review of therapeutic ultrasound: effectiveness studies. PhysTher. 2001;81(7):1339-50.

37. Ulus Y, Tander B, Akyol Y, Durmus D, Buyukakıncak O, Gul U, et al. Therapeutic ultrasound versus shamultrasound for the management of patients with kneeosteoarthritis: a randomized double-blind controlled clinical study. Int J Rheum Dis. 2012;15(2):197-206.

38. Luksurapan W, Boonhong J. Effects of phonophoresis of piroxicamand ultrasound onsymptomatic knee osteoarthritis. Arch Phys Med Rehabil. 2013;94(2):250-5.

39. Hoppenrath T, Ciccone CD. Is the reevidence that phonophoresisis more effective than ultrasound in treating pain associated with lateral epicondylitis? Physi Ther. 2006;86(1):136-40.

40. Rosim GC, Barbieri CH, Lanças FM, Mazzer N. Diclofenac phonophoresis in human volunteers. Ultrasound Med Biol. 2005;31(3):337-43.

41. Akinbo S, Owoeye O, Adesegun S. Comparison of the Therapeutic Efficacy of Diclofenac Sodiumand Methyl Salicylate Phonophoresis in the Management of Knee Osteoarthritis. Turk J Rheumatol. 2011;26(2):111-9.

42. McAlindon TE, Cooper C, Kirwan JR, Dieppe PA. Determinants of disability in osteoarthritis of the knee. Ann Rheum Dis. 1993;52(4):258-62.

43. Cubukcu D, Sarsan A, Alkan H. Relationships between Pain, Function and Radiographic Findings in Osteoarthritis of the Knee: A Cross-Sectional Study. Arthritis. 2012;2012:1-5.

44. Hart HF, Collins NJ, Ackland DC, Crossley KM. Is impaired knee confidence related to worse kinesiophobia, symptoms, and physical function in people with knee osteoarthritis after anterior cruciate ligament reconstruction? J SciMed Sport. 2015;18(5):512-7.
45. Holla JF, Steultjens MP, van der Leeden M, Roorda LD, Bierma-Zeinstra SM, den Broeder AA, et al. Determinantsof range of joint motion in patients with early symptomatic osteoarthritis of the hip and/or knee: an exploratory study in the CHECK cohort. Osteoarthritis Cartilage. 2011;19(4):411-9.

46. Petterson SC, Barrance P, Buchanan T, Binder-Macleod S, Snyder-Mackler L. Mechanisms Undlerlying Quadriceps Weakness in Knee Osteoarthritis. Med Sci Sports Exerc. 2008;40(3):422-7.

47. Kumar D, Karampinos DC, MacLeod TD, Lin W, Nardo L, Li X, et al. Quadriceps intramuscular fat fraction ratherthna musclesizeis associated with knee osteoarthritis. Osteoarthritis Cartilage. 2014;22(2):226-34.

48. Slemenda C, Heilman DK, Brandt KD, Katz BP, Mazzuca SA, Braunstein EM, et al. Reduced quadriceps strength relative to body weight: a risk factor for kne eosteoarthritis in women? Arthritis Rheum. 1998;41(11):1951-9.

49. Pisters MF, Veenhof C, van Dijk GM, Dekker J; CARPA Study Group. Avoidance of activity and limitations in activities in patients with osteoarthritis of the hip orknee: a 5 year follow-up study on the mediating role of reduced muscle strength. Osteoarthritis Cartilage. 2014;22(2):171-7.

50. Lementowski PW, Zelicof SB. Obesity and osteoarthritis. Am J Orthop (BelleMead NJ).2008;37(3):148-51.

51. Conroy MB, Kwoh CK, Krishnan E, Nevitt MC, Boudreau $\mathrm{R}$, Carbone LD et al. Musclestrength, mass, andquality in older menand women with knee osteoarthritis. Arthritis Care Res (Hoboken). 2012;64(1):15-21.

52. Ghasemi A, Zahediasl S. Normality Tests for Statistical Analysis: A Guide for Non-Statisticians. Int J Endocrinol Metab. 2012;10(2):486-9.

Received in 09/03/2015

Recebido em 03/09/2015

Approved in 08/18/2016

Aprovado em 18/08/2016 
